Georgetown University Law Center

Scholarship @ GEORGETOWN LAW

2007

Restorative Justice: What is it and Does it Work?

Carrie Menkel-Meadow

Georgetown University Law Center, meadow@law.georgetown.edu

Georgetown Public Law and Legal Theory Research Paper No. 1005485

This paper can be downloaded free of charge from:

https://scholarship.law.georgetown.edu/facpub/583

http://ssrn.com/abstract=1005485

3 Ann. Rev. L. \& Soc. Sci. 161-187 (2007)

This open-access article is brought to you by the Georgetown Law Library. Posted with permission of the author. Follow this and additional works at: https://scholarship.law.georgetown.edu/facpub

Part of the Criminal Law Commons, Dispute Resolution and Arbitration Commons, and the International Law Commons 


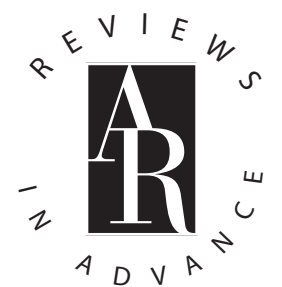

\title{
Restorative Justice: What Is It and Does It Work?
}

\author{
Carrie Menkel-Meadow \\ Georgetown University Law Center, Washington, DC 20001; \\ email: meadow@law.georgetown.edu
}

Annu. Rev. Law Soc. Sci. 2007. 3:10.1-10.27

The Annual Review of Law and Social Science is online at http://lawsocsci.annualreviews.org

This article's doi:

10.1146/annurev.lawsocsci.2.081805.110005

Copyright (c) 2007 by Annual Reviews. All rights reserved

1550-3585/07/1201-0001\$20.00

\section{Key Words}

reconciliation, reintegration, community, victims, offenders, criminal law, crime and punishment, human rights, reparations, international law

\begin{abstract}
This article reviews the now extensive literature on the varied arenas in which restorative justice is theorized and practiced-criminal violations, community ruptures and disputes, civil wars, regime change, human rights violations, and international law. It also reviews-by examining empirical studies of the processes in different settingshow restorative justice has been criticized, what its limitations and achievements might be, and how it might be understood. I explore the foundational concepts of reintegrative shaming, acknowledgment and responsibility, restitution, truth and reconciliation, and sentencing or healing circles for their transformative and theoretical potentials and for their actual practices in a variety of locationsfamily abuse, juvenile delinquency, criminal violations, problemsolving courts, indigenous-colonial-national disputes, ethnic and religious conflicts, civil wars, and liberation struggles. Restorative justice, which began as an alternative model of criminal justice, seeking healing and reconciliation for offenders, victims, and the communities in which they are embedded, has moved into larger national and international arenas of reintegration in political and ethnic conflicts. This review suggests that there are important and serious questions about whether restorative justice should be supplemental or substitutional of more conventional legal processes and about how its innovations suggest potentially transformative and challenging ideas and "moves" for dealing with both individual and group transgressive conduct, seeking peace as well as justice.
\end{abstract}




\section{INTRODUCTION: CONCEPTS, DEFINITIONS, AND PURPOSES OF RESTORATIVE JUSTICE}

To its conceptual and practical founders (John Braithwaite, Howard Zehr, and Mark Umbreit, among others), the field of restorative justice is an effort to transform the way we think of punishment for wrongful acts. When a crime or serious bad act (which may include more classes of activity than those legally labeled criminal) occurs, it effects the victims, offenders, interested bystanders (such as family members, employees, or citizens), and the larger community in which it is embedded. To paraphrase one of the field's founders (Zehr 2002, Zehr \& Mika 1998), these bad acts or ruptures in human interaction create needs and responsibilities for the direct participants in the act, as well as for the larger society in which their act(s) occur. Restorative justice is the name given to a variety of different practices, including apologies, restitution, and acknowledgments of harm and injury, as well as to other efforts to provide healing and reintegration of offenders into their communities, with or without additional punishment. Restorative justice usually involves direct communication, often with a facilitator, of victims and offenders, often with some or full representation of the relevant affected community, ${ }^{1}$ to provide a setting for acknowledgment of fault by the offender, restitution of some sort to the victim, including both affective apologies and material exchanges or payments, and often new mutual understandings, forgiveness, and agreed-to new undertakings for improved behaviors. In its most idealized form, there are four Rs of restorative justice: repair, restore, reconcile, and reintegrate the offenders and victims to each other and to their shared community.

Restorative justice raises deep philosophical, sociological, and empirical issues. The philosophical literature focuses on the pur-

\footnotetext{
${ }^{1}$ The notion of what the community is in restorative justice is one of some controversy (Weisberg 2003).

poses and nature of wrongdoing and punishment (Gabbay 2005, Blumenson 2006) and is only briefly reviewed here. At both the philosophical and sociological level, restorative justice raises important questions about who should have power, control, and possession over crime, acts of wrongdoing, punishment, restitution, reconciliation, and community interests (Christie 1977, Menkel-Meadow 1995, Von Hirsh 2003). When an act of wrongdoing is committed, who has an interest in its rectification: the victim, the community, the offender, those affected by the act, or the larger society? Who decides what justice is: the victim (who might want vengeance or restitution), the state (who will want to deter future crimes and acts of wrongdoing, set precedents for others, and establish social control), or the community in which the wrongdoing is embedded (where motivations may vary from revenge to the desire to reclaim every community member)? Who has the power to forgive and accept restitution or reconciliation: the victim, the victim's family, the community in which the wrong occurred, or the state? What if acts of wrongdoing affect both individuals and a larger community, such as hate crimes or genocides? If crime or other acts of wrongdoing are a collective hurt or tear in the social fabric, can individuals forgive on behalf of anyone besides themselves? Are crime victims adequate proxies for the rest of a society that may define justice differently (more harshly, less harshly)? How are we to know what the proper unit of analysis is for measuring appropriate forms of punishment or restitution? What is the proper balance between victim-offender reconciliation, community peace, and social order or justice? (Similar issues have been raised in the civil sphere of dispute processing; see Menkel-Meadow 1995, 2006.) How should we integrate both the public and private aspects of crime and wrongdoing? Should right-making of wrongdoing be backward facing (punishment and legal justice) or future facing (reconciliation, restoration, and social justice)? 
Whatever one's views on these important philosophical and criminological issues, the question remains: Does restorative justice work? Does it meet its own claims of reduced recidivism, restored communities, and reintegrated offenders? Is restorative justice more efficient (less costly, more deterrent, more restitutionary) than more conventional forms of punishment? Is it more fair or just (as perceived by participants or as analyzed by external, objective, and professional measures of these illusive concepts). This article reviews the extant findings, which do demonstrate some support for restorative justice claims, while also raising questions about the (limited) conditions under which restorative justice may be most effective. The next major issue of evaluation in the field is whether even successful victim-offender restorative justice can be scaled up to national levels of political and civic reconciliation, either through truth and reconciliation-like processes or through reparations (Bradford 2005, Brooks 1999, Brophy 2006).

Restorative justice as a social practice and movement began, in its modern incarnation, in the 1970 s as a response to what was considered to be an overly harsh criminal justice system that neither effectively deterred crime nor successfully rehabilitated offenders. Championed by social workers, progressive criminal treatment professionals (including police officers and prison reformers), some lawyers and judges, psychologists, and community and peace activists, restorative justice was practiced first (Lerman 1999), and theorized later, most eloquently by John Braithwaite (1989, 1995, 1999, 2002, 2003, 2006). Restorative justice proponents suggested that by providing structured environments in which offenders and victims met and explained their injuries and hurts to each other, offenders could acknowledge and explain their bad acts, apologize, and make restitution to victims who could forgive and feel safe again. With family members or community representatives present, there would be public accountability, an inquiry into root causes of criminal or wrongful acts, and, at its best, suggestions for creative, tailored solutions. Restitutionary possibilities would emerge from facilitated dialogue. Through structured shaming (Kahan 1996, 2006; cf. Markel 2007), responsibility taking, and acknowledgment of injury done, offenders might be effectively reintegrated into their communities, and victims would no longer be frightened or traumatized by what had happened to them.

From the beginning, restorative justice practices were intended to heal at both the individual and group or social level. Attention in both practice and theory was placed on healing those directly affected by a crime or bad act and on institutional and social reform. At its most aspirational or utopian, restorative justice has been seen as a potentially transformative social practice that could, under the right conditions, obviate the need for harsh criminal punishment and incarceration. In this conception, restorative justice was linked as a social movement to community organizing, criminal justice and prison reform, the civil alternative dispute resolution (ADR) movement (Menkel-Meadow et al. 2005), and the peace movement in that it sought alternative processes for different and more humane and tailored outcomes. In its more grounded and practical institutionalized forms, restorative justice was often supplemental, not substitutive, to conventional criminal proceedings. In an early core definition of restorative justice, it is a "process that brings together all the parties affected by an incident of wrongdoing to collectively decide how to deal with the aftermath of the incident and its implications for the future" (Marshall 1998, Roche 2004). Although some think restorative justice is most appropriate in the context of small, interpersonal wrongful acts, such as petty thefts, simple assaults, drug- or alcoholrelated crimes, and family abuse, restorative justice has been adapted for cases involving murder, rape, genocide, and other serious transgressions against large groups or even a whole society (Umbreit et al. 2005, Wellikoff 2004). It has also been used effectively as 
a model for pre- or nonlegal disputes in schools, organizational and corporate conflict management, neighborhoods, communities, and families (Llewellyn \& Howse 1998).

What began as a domestic social reform movement (simultaneously developed in Australia, New Zealand, Canada, the United States, the Netherlands, Austria, and others), restorative justice and its basic principles became a process of international interest when Desmond Tutu (1999) led a truth and reconciliation process to transform and heal South African society's transition from apartheid to a just, multiracial society. Variations on indigenous [such as Rwandan gacaca (Honeyman 2004, Bolocan 2004, Raper 2005) and Ugandan mato oput (Blumenson 2006)] and newly minted restorative processes (Avruch \& Vejarano 2001) have now been used in more than 25 national efforts to move more peacefully through political, racial, ethnic, and civil wars and transitions to more peaceful, democratic, and just states. Restorative justice principles thus helped form a new field of international law and political structure: transitional justice (Teitel 2000).

Restorative justice has several foundational concepts that have now been elaborated and extended to many arenas of social and political interaction:

- Personalized and direct participation in a process of speaking and listening of both a wrongdoer (offender) and a victim of an act of wrongdoing;

- Narration of what an act of wrongdoing consisted of and the harm or injury it caused to those affected (including both direct victims and often others, including bystanders and the larger community);

- Explanation by the offender of what was done and why;

- Acknowledgment and acceptance of fault for the wrong committed by the offender with recognition of the harm caused (with apology, if not coerced);

- Opportunity for appreciation or understanding of why the wrong occurred (root causes) and, in some cases, forgiveness of the individual, without forgetfulness of the act;

- Consideration of appropriate outcomes or restitution to those wronged by all participants, including victim, offender, family members, and/or larger community, often with expert facilitation;

- Reintegration of the wrongdoer into the larger community, through apology, restitution, and/or support and social services provided (alone or in conjunction with formal punishment as well);

- Reconciliation of wronged and wrongdoer, within a renewed commitment to shared social norms (often reconstituted within the restorative process);

- An orientation to the wrongdoer that treats the act separate from the person so that the person may be redeemed as the victim/community is repaired;

- An orientation to the future, to the extent possible, to make right what was wrong and to rebuild new relationships and new communities.

These foundational concepts come from a belief that conventional legal processes (criminal, international tribunals, and even civil processes) are often ineffective in their bureaucratic separation of offender from the actual consequences of acts, in the timing of any remedial actions (delayed incarcerations or other punishments), and in the inattention to the personal nature of the wrong (both for rehabilitation of the offender and restitution of the particular harm suffered by the victim), not to mention in their failure to deter or reduce crime. Restorative justice hopes to harness the commission of wrongful acts to the making of new opportunities for personal, communal, and societal growth and transformation through empowerment of both victims and offenders in direct and authentic dialogue and recognition. It also hopes practically to reduce recidivism and reintegrate wrongdoers into more positive roles and relationships. 
At the theoretical level, most proponents of restorative justice claim that such processes reclaim the property of the crimes or conflicts from their ownership and mismanagement by the state (Christie 1977) and return them to the victims and offenders whose lives are most affected. As with the civil ADR movement, restorative justice proponents claim that outcomes can be creatively tailored to meet the requirements and needs of the situations and the parties. Thus, there will be higher rates of compliance and greater satisfaction with the process itself, encouraging belief in its legitimacy and its ability to rectify wrongs and repair broken or harmed social relationships. Restorative justice is designed to remove negative stigmatization of the individual and replace it with recognition of the wrongfulness of an act, with shaming of the act, and with reintegration of the person (Braithwaite 2002; Strang 2001, 2004). As an ideology and as a practice, restorative justice often appeals across the political spectrum, with liberals seeking criminal justice reform through personalized treatment, compassion, and understanding for socially disadvantaged offenders, and conservatives approving of offender accountability, responsibility, and restitutionary payments to victims (Barnett 1977). When it works most effectively, restorative justice enhances participatory and deliberative democracy and can promote community building, political legitimacy, and the development of new social and legal norms. Progressive theorists and practitioners see in restorative justice another form of participatory deliberative democracy; conservative theorists see devolved and localized governance for crime control.

Although there are many contested theoretical and practical issues in the uses of restorative justice at its different levels (personalistic wrongs, less serious crimes, serious crimes, state crimes, crimes or wrongs against humanity) that are reviewed below, recent scholarship (Strang 2004, Johnstone 2003, Roche 2004, Strang \& Braithwaite 2000, Minow 1998) on these issues has en- abled a relatively coherent set of issues, research questions, and objections to be developed across levels of analysis and uses of restorative processes. Such issues include:

1. Whether restorative justice processes are effective in meeting their own claimed advantages, such as reduced recidivism rates; increased rates of reintegration to a nonoffender life; movement toward reconciled, postconflict societies;

2. Whether victims feel coerced or blackmailed to participate, forgive, forget, and forego (desires for revenge or other retributivist goals) (Acorn 2004, Brown 1994);

3. Whether offenders feel coerced to confess, apologize, and waive the rights of the criminally accused (Dolinko 2003, Delgado 2000, Brown 1994);

4. Whether restorative processes-like other alternative processes that focus on direct, but informal, narrativeprivilege some (the articulate, the verbal) and disadvantage others [the less verbal; the racially, gendered, or class-based disadvantaged (Young 1990, 2000; Daly 2002, 2005; Cahn 2006)];

5. Whether certain classes of wrongdoing should never be submitted to restorative processes, e.g., serious crimes such as murder, rape, or wrongdoing in which society as a whole, not just individuals, is affected, such as genocide or hate crimes (Robinson 2006, Rugge \& Cormier 2005);

6. Whether particular wrongdoers or offenders (or victims) should be excluded from restorative processes, e.g., repeat offenders, the mentally impaired, those who are remorseless;

7. Whether psychological or socially based communication technologies at the individual level are effective for macro institutional, national, and larger social problems;

8. Whether restorative justice can or should substitute entirely for state and 
formal criminal sanctions and punishments or whether it should be a totally informal and voluntary supplementary process;

9. Whether restorative justice is more economically and criminologically efficient (less costly, more deterrent) than conventional criminal justice methods;

10. Whether a focus on future remediation or right-making diminishes important concerns about blame for past wrongs (Menkel-Meadow 2004, Grillo 1991);

11. Whether individualized forms of restorative justice can meet the requirements of equity-based justice or equality when similarly situated offenders are provided with differential outcomes (Robinson 2006);

12. Whether privatization of justice in the criminal context (whether individual or at larger state levels) deprives us of the public function of courts, tribunals, punishments, and precedentsetting (Luban 1995);

13. Whether private criminal justice can operate within the shadow of the law, with both the potential coercion of the state as a threatened alternative, or as a weak substitute where there is no formal law enforcement (international criminal law);

14. Whether participation in restorative justice procedures enhances both individual and communitarian sensibilities for empowerment, fairness, legitimacy, satisfaction, and social justice;

15. Whether restorative justice is a spiritual, utopian project, with a faith in human ability to be transformed, at both individual (Katz 1990) or group levels (Gibson 2004a), and whether it can be harnessed to practical, institutional, large-scale social and legal change.

This article reviews the claims made for restorative justice and the difficult and compelling issues raised by its use and offered by its critics to discount its achievements and possibilities. I begin by recounting some of the history of restorative justice in its various forms, with its differentiated claims. I then explore some of the most trenchant critiques that have been made of restorative justice at philosophical, social, political, jurisprudential, and practical levels. Next, I report on what we know to date about how restorative justice actually works from a variety of empirical sources, including several meta-analyses performed by others. Finally, I suggest what issues and challenges lie ahead for both the use and assessment of restorative justice efforts in individual, community, national, and international efforts to deal effectively with humaninflicted harm.

\section{FORMS AND MODELS OF RESTORATIVE JUSTICE}

Although in one sense restorative or restitutionary justice is as old at least as the earliest forms of classical justice in Greek, Arab, and Roman legal culture (Braithwaite 2002), modern restorative justice traces its origins to objections to both retributivist and failed rehabilitative models of criminal law and punishment. Victim control of the prosecution of wrongful acts was a common practice before the modernization of the criminal justice system in the late Middle Ages in Europe (Langbein 2003) relocated the management of crime from private citizens to the state. State control of crime developed to provide revenue for the state (in fines and punishments) and more order and control (and equity) in the treatment of offenders. State control of criminal acts was also a product of the fear of vigilante or vengeance motives on the part of victims, which actually perpetuated violence, as needs for less bloodthirsty and more orderly outcomes were required, not only as religious, social, and humanitarian values evolved, but also to provide some predictability for the growing commercial society and increasingly centralized political order (Thompson 1976). Although fines and jail terms began to substitute for blood feuds in postmedieval Europe, elements of violent 
retributivist and vengeance-seeking systems of justice continued to coexist with local restorative forms of community moots or mediation in many cultures. The history of criminal justice and punishment is one of increasing state control and surveillance (Foucault 1979), with concomitant increased costs of public institutions and public responsibility, with little demonstrated reduction of crime, violence, or antisocial acts (cf. Zimring 2006).

The twentieth century was certainly the most violent of all centuries at nation-state, group, and individual levels, even with the modern criminal and penological apparatus that had developed by then. Aside from Anglo and middle European criminal justice models of punishment (incapacitation, incarceration, retribution, rehabilitation), other legal cultures have long focused on restorative, reparative, or restitutionary forms of justice, including community moots, wise elder mediation, religious forms of repentance and reparation, and various forms of communal conferencing (nanante, ubuntu, gacaca) in the Middle East, Africa, and Asia and peace circles in indigenous American (both North and South) cultures. All these forms of justice or dispute resolution involve some narration before victims, offenders, family members, supporters, community members, and leaders, with communally arrived at outcomes (fines of animals, crops, other goods, or money; reparative work; and often ritual ceremonies of healing and forgiveness, including the sharing of common food and drink, as well as dances, songs, and other expressive activities). Most reparative forms of justice were scaled to smaller communities where mobility for both offenders and the community was limited and continuing face-to-face contacts with community members were the norm.

As state control embraced more social control of criminal offenders, both through formal legal processes and therapeutic intervention models, reformers began to experiment with new forms of handling (I never say managing) wrongdoing. In the early 1970s, both in Canada and the United States, contem- poraneously with similar movements in civil and family law toward mediation, experimental programs in victim-offender reconciliation programs (VORP) or victim-offender mediation (VOM) (Umbreit 1994) were established alongside or within progressive court systems, some as diversionary programs for minor crimes, others as independent processes. By the mid-1990s, there were hundreds of programs in many states and provinces of the United States and Canada. These early programs focused on facilitated conversations of wrongdoers, victims, and family members both as supporters and as possible disciplinarians or enforcers. These programs sometimes served as alternatives to state prosecutions (dismissals if victims agreed and were otherwise made whole). VORP and VOM were often founded by social reformers, progressive criminal law professionals (including police, probation and parole officers, and social workers and some lawyers and judges), and, notably, by religious groups, such as the Mennonites, who brought their reparative philosophy to bear on all forms of conflict resolution (Zehr 1990, Lederach 1997).

Some of the developments in the 1970s were sparked by First Nation practices in Canada (Stuart 2001) for "peace or sentencing or family circles" used both for internal wrongs committed within tribes and then later expanded to First Nation land and other disputes with the larger nation-state (Bradford 2005). These practices enlarged the notion of who was a proper participant or stakeholder in conflicts involving harm to other members of the community. A more flexible, tailored, and communitarian sense of justice or fairness, including group responsibility for bringing individuals back into the community, characterized many of these programs. "Healing or peace circles" of a variety of North American native groups, including the Navajo (Yazzie \& Zion 1996), brought native practices to the attention of conventional court systems. Processes including "talking sticks" that rotate among participants and equalize who will talk (especially in leaderless groups) are radically 
different from legalistic and adversarial confrontations. The purpose of such conferences is often not to assess fault or guilt (with factfinding), although there is narration of what happened and why, because usually fault or guilt is admitted. The purpose of the circle or conference is to consider the best ways to make the victim whole or compensated and to consider various forms of treatment or reintegration of the wrongdoer. With the emphasis on remedial approaches (for both victims and offenders), considered from a collectivity (the community, tribe, family, or other representatives), power is not located in a single judge, and the norms that are referenced may be negotiated and interpreted for particular cases, with less emphasis on formal rules and standards. These processes have many variations, including referral back to courts if wrongdoers do not admit fault or victims are not satisfied with apologies or restitutionary offers when laws have been violated. In other cases, the state may defer to some other form of authority (Indian tribes, local law enforcement, etc.), provided there is full participant consent or other legal authorization.

Perhaps the greatest and deepest impact of these new processes was seen in New Zealand, where family conferencing modeled on both traditional Maori and modern practices developed into a mandatory model for juvenile justice (Maxwell \& Morris 1993). Here the movement represents collaboration among mainstream conservative and social democratic political parties, Christian profamily groups, and Maori philosophy and participation (Braithwaite 2002). In such family conferences, alternative structures to conventional adversary adjudication involve the juvenile offender, teachers, social workers, family members, victims, and others who jointly develop a package of restitutionary payments or service, apologies, and plans for future behavior, often in lieu of incarceration. In sentencing circles, a community group helps develop programs and proposals for compensating victims and preparing behavioral plans for amelioration of the conduct of the offender. Such pro- grams, of course, have their critics (see below), both for coercing compliance and also for reduction of criminal defendant rights in nations with strong civil liberties protections (Delgado 2000). There is also some evidence that, when used in smaller, homogeneous communities (which are felt to be more oppressive to some adolescents than the cold state), there is an increased risk of flight from the community (Marshall 1998).

In the United States, the states making most use of these programs are Minnesota, Vermont, Wisconsin, Maine, New Mexico, Pennsylvania, and Montana, which employ various forms of victim-offender programs for juveniles and for postconviction, probation, parole, and "creative" sentencing. Less use is made currently at the federal criminal level because of determinate sentencing laws (Beale 2003), although in earlier periods, the federal courts varied by region in how they delivered tailored justice to particular offenders, with contrasting retributivist and rehabilitative goals (Utz 1978). A new development includes "problem-solving courts" (Kaye 1997, Berman et al. 2005) in which restorative and rehabilitative principles have made their way into the formal justice system, as specialized courts in drug offenses, vice, abuse, neglect, and other family issues have developed more reparative sentences, including personalized treatment programs, some elements of restorative shaming, and some structured encounter with victims, as well as regular reporting and accountability (e.g., drug tests) to the court itself (Dorf \& Sabel 2000).

Restorative justice programs are intended, in ideology, to be purely voluntary, but aspects of restorative justice have been co-opted into mandatory diversionary and formal court programs, raising questions of philosophical purity and efficacy and challenging efforts to measure the impact of these programs. Some models of restorative justice have been used in prisons, concurrent with and adjunct to formal punishment, and observers fear that some offenders may pay twice with formal criminal sanctions and demands for less formal 
restitutionary or shaming rituals that reduce their human dignity (Nussbaum 2004). Restorative justice processes can also be used following release, as conditions of parole or probation, connecting the offender to agreements with victims or the community for social service, compensation, or accountability for behavioral change. Although restorative justice is motivated by those seeking humanistic integration, it is easy to see how some restorative justice forms can appear oppressive, reducing freedom of action, and individual agency and requiring intrusive surveillance and accountability that can devolve into counterproductive resentment.

Restorative justice has, in recent years, informed a variety of other legal and political processes. John Braithwaite argues for its effectiveness as responsive regulation in matters of corporate and public policy regulation. When state regulators engage in negotiated conversations with managers of corporations and industries (such as nursing homes, trade groups, commercial enterprises), Braithwaite (2002) argues, compliance is greater and dialogues allow more realistic, flexible, and contingent enforcement of important legal standards (see also Hawkins 1984).

Dispute resolution theorists and practitioners have argued that public and deliberative encounters in regulatory, civil, and criminal matters can be seen as a new form of governance, promoting healthy democratic deliberation that is more participatory, legitimate, and flexible in its legal and social problem solving when matters are openly negotiated with many stakeholders and when multiple issues and multiple parties are involved in the deliberations (Menkel-Meadow 2004, Elster 1995, Bohman 1996).

In the 1990s, restorative justice practices moved outward from individual acts of wrongdoing to the systematic wrongdoing of civil and ethnic wars (by both intra- and international state and nonstate actors) and illegitimate regimes such as apartheid. The use of TRCs and similar public panels of encounters of victims and offenders and the larger nation-state and international community has given rise to whole new institutions of justice (Avruch \& Vejarano 2001, Minow 1998, Stromseth et al. 2006). These truth commissions are intended to provide a new national narrative as victims seek answers and information about their individual family members [what happened to the disappeared (Argentina, Chile), the murdered, or the incarcerated (Guatemala, Rwanda, South Africa)], as well as the truth about statesanctioned violence and harm (Sierra Leone, East Timor). As discussed more fully below, the challenge for these various and quite diverse TRCs has been to ensure participation by both victims and perpetrators, which in many cases is not a direct encounter as in more conventional criminal restorative justice practices, in settings where there is mostly talk or testimony and not real punishment or restitutionary relief.

At the national or institutional level of restorative justice, the goals may be quite different than in more individualized acts of wrongdoing. The commissions are designed to heal the nation-state or civil community by allowing many narratives of hurt and harm to be told and by creating new collective narratives of the truth so that a society can begin anew with transformative understandings of both its past and its future. Like the use of restorative justice in more individual settings, the efficacy and effectiveness of these processes have been debated and questioned (see below), but these processes are clearly evolving and offer great promise of adapting to different political, cultural, and historical contexts and may ultimately transform our conceptions of international justice. As is more fully explored below, as scholars and political activists assess and debate their effectiveness, there are particularly rich encounters between the international human rights community (with rights-based conceptions of justice) and the international conflict resolution and peacekeeping communities (with more realist and pragmatic conceptions of postconflict regimes). Differences of theoretical 
paradigms, of assumptions about human behavior, of philosophies, and of commitments (such as to the rule of law or to pragmatic, informal actions of nongovernmental organizations) and practices may themselves have to be mediated to make these new forms of justice meet their aspirational goals, either alongside conventional legal structures (with conventional international or national prosecutions of the most serious atrocities) or as substitutes for them (in less serious cases in which redemption, reassimilation, or even co-optation of past aggressors may be possible or desirable for security and continuity of regimes). The newer forms of truth and reconciliation practices combine tiered systems of prosecution (for most serious crimes) and confession and restorative justice for less serious offenses (Honeyman 2004, Hayner 2001). Whether these alternative institutions are public or private is also a crucial issue. The South African TRC proceedings were televised to the whole nation, but virtually all of the Latin American commission proceedings (Argentina, Chile, and Guatemala) were privately conducted (even with publication of formal reports).

\section{CRITIQUES OF RESTORATIVE JUSTICE}

Most proponents of restorative justice appeal in visionary, optimistic, and aspirational terms for a new human sensibility to emerge from the transformative effects of dialogue, conversation, empowerment, and understanding, from individual juvenile offender advocates to architects of the most complex truth and reconciliation governmental processes or formal state institutions, such as problem-solving courts. The claims made on behalf of restorative justice are simultaneously instrumental, incremental, and grand:

- Restorative justice enhances understanding of the root causes of crime and conflict;

- Outcomes reached in restorative justice are more likely to be complied with;
- Restorative justice processes reduce recidivism rates;

- Restorative justice offers the possibility of reclaiming, repairing, and transforming individual wrongdoers and reintegrating them into productive activity;

- Participants in restorative justice processes are more likely to develop fellow-feeling, empathy, and a sense of moral responsibility, mutuality, and reciprocity;

- Restorative justice processes enhance community building, community norm development, and democratic participation by increasing the number of stakeholders who are involved in its deliberations;

- Restorative justice permits more real, less formal, less stylized or legal human communication and interaction, producing more authentic understanding;

- Restorative justice processes are richer at expressing a variety of often competing justice values simultaneouslyacknowledgment of fault, recognition of consequences that flow from wrongful activity (punishment, remorse), compensation to victims, social learning and healing, mercy, as well as moral judgment-and are thus more creative and flexible and represent a form of responsive justice (Nonet \& Selznick 1978) that is humanely civilized and not as brittle as formal adversarial justice structures;

- Processes using restorative justice values are more likely to engage individuals in voluntary commitments for undertakings to others and self and to encourage self-empowerment and self-esteem;

- The underlying values of restorative justice promote a positive redemptionist and ameliorative view of human behavior, with a positive hope that even the worst among us can be transformed to consider the common good and the best for other human beings; 
- Outcomes produced by participatory restorative justice processes are more tailored to the specific needs of individuals, groups, communities, and nations; they can be bargained for with more nuance, detail, and accountability than those produced by formal and overbooked systems of justice;

- Restorative justice is potentially less costly and more efficient both in monetary and deterrent effects than conventional penological practices;

- If the principles of restorative justice were to gain ascendancy, the criminal justice system would be radically transformed (less punitive and more responsive), if not eliminated.

Since the practices of restorative justice in all of the forms described above have been developing and attempting to express these aspirational values, a core of critiques of restorative justice has emerged at different levels and from the perspectives of different disciplines. There are empirical claims that restorative justice does not meet its own claims (see next section) (Braithwaite 2002, Daly 2002, Van Ness 1993); philosophical and sociological claims that humans continue to carry base retributivist and vengeful motivations that are impervious to so-called transformative processes (Acorn 2004); legalistic claims that restorative justice unfairly coerces and manipulates its participants to forgive (victims) or confess and accept harsher terms (offenders) than legal rights and rules would permit in formal justice institutions and that restorative justice does not deliver equitable or equal justice (Dolinko 2003, Delgado 2000); anthropological critiques that concepts in restorative justice ideology are culturally specific and not universal (Avruch \& Vejarano 2001) and that notions of community are social constructs and can be manipulated for bad ends (Weisberg 2003); and political claims that restorative justice processes will be manipulated, corrupted, co-opted, and deformed to produce oppression, more state surveillance and discipline, and more inappropriate social control (Abel 1982, Levrant et al. 1999).

In addition to these critiques, specific critics have suggested that, like civil ADR, restorative justice privatizes that which should be public (Luban 1995), prevents precedents and rule generation for community norm development, and hides its outcomes from measurement and evaluation. The location of restorative justice (whether in or alongside courts or as private conferencing sessions) problematizes the relation of the state to law enforcement and shared governance with private entities (a larger issue that clearly implicates more than restorative reforms in this age of public-private partnerships).

Criminologists worry that restorative justice will lead to subjective, nonobjective, and nonrational assessments of harm and need and will produce great inequities for both victims and offenders. What is extremely painful to one victim may be tolerable for another. Whether victims receive recompense and restitution will depend not on the quality of the offense, but on the resources of the offender. Philosophers such as Nussbaum (2004) decry the potential degradation and loss of humanity that can come from compelled shaming. Acorn (2004) argues similarly about the effects of coerced compassion on the part of victims, who have been seriously harmed and are made to feel ashamed about their desires for punishment, vengeance, and retribution. In these claims, we see that the very promise of restorative justice to be more authentic has the potential to be less authentic than other forms of structured and rule-based discourse because of its compelled or expected narratives. When the harm is not only personal but social, how can the offender satisfy the needs of the community for rectification and safety with a simple (even if authentic) apology (Robinson 2003, 2006)?

Within the restorative justice movement itself, practitioners and theorists have their own worries (Braithwaite 2002, pp. 13768) that offenders may be stigmatized in a different, but harmful, way than they are 
stigmatized in formal court proceedings; that victims can feel revictimized in their retelling of pain or injury suffered [comparable to the rape victim's dilemmas in the formal adjudication system (Matoesian 1993)]; that oppressive or false communities in societies that are actually heterogeneous will attempt to impose their own values on participants in the process; or that even with community homogeneity more conservative or majoritarian values may gain ascendancy and dampen individual freedoms (Weisberg 2003). Although conceived as a part of a progressive movement for social justice, the appeal of restorative justice to the Christian Fundamentalist Right in the United States has caused some to be concerned about whether restorative processes will be used for antiprogressive ends (imposing conservative, antiliberationist, narrowly religious, or monocultural values). Or, with less conservative ends, governments may simply co-opt such processes to achieve their ends (diversionary programs, docket clearing, more social control and surveillance devolved to nonstate actors) and thus routinize and make less authentic the human encounter and engagement contemplated by restorative justice proponents. Like civil forms of ADR in such processes as consensus building, collaborative governance, negotiated rulemaking, and multi-agency mediation, some worry that the separation of powers and accountability in constitutional governments will be obscured and made difficult to monitor. Lawyers, in particular, worry about how informal processes, while serving some ends of responsive and flexible justice, can erode other important values-individual civil rights, standards for convictions, rights of appeals, written opinions, and accountability of decision makers.

Feminists have been strong critics (and proponents in other contexts) of restorative justice models that decriminalize violence against woman and seek lesser punishments and no incarceration for wrongful acts that have only recently achieved some form of legal recognition (Daly 2005, Stubbs 1995). Practitioners worry that processes that are struc- tured around dialogue and narrative (Young 2000) may privilege the verbal and well educated and disempower those without education or other resources. And others worry that restitution commodifies crime and wrongdoing by allowing offenders to buy their way out if they can (Kahan 2006). Imprisonment, at least in theory, is a great equalizer in incapacitation.

Finally, restorative justice requires wellintentioned, nonmanipulative participants and sufficient resources to allow authentic encounters and dialogue to occur. Thus, even for some proponents of restorative justice, there is a fear that restorative justice can only work with large commitments of time, resources, and skilled individuals and must necessarily be deformed and watered down to ritualized imperfections if it is assimilated, aggregated, and institutionalized without sufficient care and resources.

\section{EMPIRICAL ASSESSMENTS OF RESTORATIVE JUSTICE: DOES IT WORK?}

There are many challenges in assessing the claims of both proponents and critics of restorative justice at the conceptual and methodological levels. Most importantly, as in assessments of all comparative forms of justice or legal case processing, including civil dispute resolution, it is virtually impossible to conduct controlled experiments or treatments of submitting the same matter to different treatment conditions for comparison. In both criminal justice matters and larger conflicts, ordinarily there is only one treatment of the matter or, if several treatments are used, the treatments are used for different purposes or at different times [such as use of VOM for remedy but not guilt assessment, triaging, or grading of crimes against humanity that are assigned to formal prosecution or more restorative processes, such as gacaca in Rwanda (Bolocan 2004)]. So, although a few controlled studies are emerging in which there is random assignment of cases 
to either restorative justice or more conventional models of process, the bulk of empirical evaluations of restorative justice efforts focus on aggregate comparison data, with attempts at matched cases or data sets of different forms of treatment or intervention. Examples include efforts to assess (a) comparative compliance rates with agreements or judgments; (b) satisfaction rates for victims, offenders, professionals, and the larger community with different processes and outcome possibilities; $(c)$ reoffender or recidivism rates; (d) reduction of violence generally [community measures beyond those of participants in the process (Zimring 2006)]; and (e) in the case of TRCs, whether postconflict societies build efficacious systems of governance with legitimacy, compared with societies that have not used such processes (Stromseth et al. 2006).

The second challenge is to define and operationalize the meaning of variables assessed. As several new meta-analyses have shown, over the course of many years of study, such variables as reoffense rates vary enormously from study to study, thereby greatly confounding analysis. In some studies reoffense is measured in short time intervals (six months); in others longer (up to two years or more). Some studies cut finely and look at degrees of severity of offense (simple and single property offenses, simple to repeated assaults) and others look only at whether there is a subsequent conviction or, quite differently, simply another arrest. Because it is easiest to measure, with exit interviews or follow-up methods, the most common factor studied is a crude measure of satisfaction with the process (and/or outcome), tracking the now rich and robust findings of procedural justice attitudes (MacCoun 2005, Thibault \& Walker 1975). These findings demonstrate that the processes generally favored are informal processes that give participants voice and that have some cathartic effect in response to the dispute or act of wrongdoing. And these informal processes are favored even when parties lose (or do not gain much) in outcomes. Here again, the comparisons are analogical, rather than experimental.

Aggregate studies compare satisfaction rates of those who have used the conventional justice system with those who have attended some alternative process (Kakalik et al. 1996, Lind et al. 1989), but it is virtually impossible for the same participant to compare treatment in the two types of processes in the same case, leaving open the possibilities that case factors and other variables may account for process satisfaction. For example, in one of the most rigorously designed tests of comparative civil case processing, LaFree \& Rack (1996) found that race and ethnic matching of thirdparty neutrals (whether mediators or judges) with participants (Anglo-white, Hispanic, or African American) accounted for some of the comparative satisfaction rates of disputants (and also explained some of the variance in outcomes in the two processes (mediation or adjudication).

At the level of assessing the more ambitious truth and reconciliation or societal restorative processes, measurements are even more complex and difficult to assess. Should individuals be polled about satisfaction (those who have participated and those who have not)? Is it possible, as some political scientists have attempted, to compare rates of internal conflict and civil wars over time and between nation-states and also to measure aggregate levels of international conflict (Stein 1993) when different conflict resolution processes are used? As the growing literature on TRCs and postconflict interventions indicates, there are great variations in the purposes, structures (direct or indirect encounters and testimonies, amnesties or punishment, types of matters subject to informal processes, publicity and accessibility of such processes, location, type of third-party interventions or facilitations), and functioning of these innovations in justice. Comparisons across widely different political, social, and cultural contexts may be quite difficult.

Despite these methodological problems, the emerging data often provide not only 
confirming or disconfirming information about the claims and hypotheses about restorative processes, but also, in some cases, information about new and perhaps unintended effects of such processes, such as Gibson's (2004a,b) findings on the development of human rights consciousness among those who viewed (on national television) the South African Truth and Reconciliation process, even if they did not participate directly (see below).

Here I present an overview of what studies to date have revealed about how restorative justice is working or is perceived to be working, in a variety of locations, with great variations in purpose, structure, and use.

The greatest claims for restorative justice, in its most conventional forms in criminal justice-that it creates greater compliance with agreements or judgments, reduces imprisonment (and therefore costs to the system), provides greater satisfaction for both victims and offenders, and reduces recidivism rates-have all been substantiated in a variety of different studies on at least three continents (North America, Australia and New Zealand, and Europe), despite methodological difficulties in almost all settings. Comparisons between systems (restorative and conventional-retributivist) are difficult when the participants do not engage in both types [and satisfaction rates with informal processes tend to be high, whether in civil cases (mediation, arbitration, or other forms of ADR) or criminal cases (see Lind et al. 1989, Kakalik et al. 1996)].

Some studies focus on participation rates, noting that even when referred by courts (in less than voluntary settings) many offenders choose to admit guilt and attend mediation with their victims. (In virtually all court programs, defendants who do not admit guilt and instead seek trial are not referred to VOM. Thus, how voluntary a guilt admission is remains a worrisome issue.) Participation rates for victims range from $40 \%$ to $60 \%$ of those referred. Interestingly, participation rates for victims go up when more time elapses be- tween referral and participation in cases involving personal injury (assault), but decrease when more time elapses in cases involving property (theft, vandalism) (Umbreit et al. 2005). There is a curvilinear relationship for participation rates of victims and the seriousness of the offense, with participation rates lowest for less serious offenses ("I can't be bothered") and for the most serious (fear of the offender or reliving the trauma in serious bodily harm cases) (Coates \& Gehm 1985, Wyrick \& Costanzo 1999).

Many studies have demonstrated high satisfaction rates on the part of both offenders and victims who feel they were treated better in restorative justice processes than in the criminal justice system (Poulson 2003, reviewing 7 selected studies out of 100 on psychological outcomes of restorative justice), often with satisfaction rates greater by a factor of 3 to 4 . Studies in such diverse locations as Bethlehem, Pennsylvania (McCold \& Wachtel 1998); Brooklyn, New York (Davis et al. 1980); Canberra, Australia (Strang et al. 1999, Strang 2001); Israel (Umbreit \& Ritter 2006); a multi-state U.S. study (Umbreit \& Coates 1992, Umbreit et al. 2001); Canada (Umbreit 1995); and the United Kingdom (Umbreit \& Roberts 1996, Marshall \& Merry 1990); along with meta-analysis of multiple studies (Latimer et al. 2001), with diverse sets of victims (female, young, old, low and middle socioeconomic classes) and offenders (most, but not all of the studies focus on juvenile offenders, with increasing attention to adult offender programs as restorative justice practices expand) all find that victims have satisfaction rates higher than what they had expected to gain from a process following injury and harm. Offenders are much more likely to feel they have been treated fairly. Offender satisfaction rates with restorative justice compared with court processes tend to be higher than victims' satisfaction (typically because, in minor offenses, participation in restorative justice proceedings may eliminate other forms of punishment, including incarceration, although in some programs offenders might 
have had their cases totally dismissed in a more conventional setting).

Both victims and offenders report satisfaction with their ability to narrate and explain more fully both the harm and injury that wrongdoing caused in particular circumstances and the reasons for committing bad acts. On the victim side, there is a slightly lower perception that their opinions were taken more seriously in restorative justice than in court, compared with offenders (Poulson 2003). And, in an important and rigorous analysis in Australia, victims whose restorative justice proceedings were badly handled or did not take place were the least satisfied [less satisfied than court users and participants in more successful restorative justice proceedings (Strang 2001)]. Thus, the quality of the restorative justice process may be especially important when there are high expectations about what it can accomplish. Participants generally expressed satisfaction with the fairness of mediators or third-party facilitators over judges [by a factor of 2.3 for victims and 6.0 for offenders (Poulson 2003)].

Victims have been satisfied with what they perceive to be greater accountability in restorative justice (Poulson 2003), and, not surprisingly, victims were more likely to forgive the offender in restorative justice processes than in court proceedings, probably because offenders are much more likely to apologize [6.9 times more likely according to Poulson's (2003) meta-analysis] than in court proceedings.

Since the beginning of the 1990s, researchers have attempted to track compliance rates with reparation and compensation agreements. Although many argue that restorative justice does not require an agreement but rather seeks understanding and dialogue, studies document that agreements for some sort of restitution are highly likely to occur [more than $90 \%$ in VOM programs in which there is face-to-face contact, with some form of restitutionary agreement being reached in the vast majority of cases (Umbreit et al. 2005, Umbreit 2001, Umbreit \& Coates
1992)]. Compliance rates range from a high of $100 \%$ to usually no lower than about $75 \%$, in comparison with control groups with diversionary or other sentences from courts (see, e.g., Haley \& Neugebauer 1992, Marshall 1998, Kuhn 1987, McCold \& Wachtel 1998). Latimer et al.'s (2001) meta-analysis of eight studies with a control group found that restitutionary compliance was $33 \%$ higher in restorative justice cases than in the control cases (in court). Other studies in the United States have found comparisons of compliance of $81 \%$ completion rates in restorative justice with $58 \%$ completion in court cases (Umbreit et al. 2005). And in a randomly assigned treatment evaluation of six different programs, $89 \%$ completion was found in restorative justice, compared with $75 \%$ completion in courts (Ervin \& Schneider 1990).

Satisfaction rates for victims are often attributed to the nonmaterial or human aspects of the process-the ability to explain in regular language (not court-stylized admissible evidence) what the harm caused has meant for the individual, to learn facts relating to the wrongdoing, and to learn a little bit about why an offender does bad things. In his meta-analysis of seven studies, Poulson (2003) found that victims who participated in restorative justice proceedings were half as likely to feel upset about the crime afterwards than were victims who went to court. In the places where restorative justice is used in very serious crimes, such as murder or serious felonies, the effects of restorative justice are often only in this nonmaterial realmaccountability and apology by the wrongdoer and some relief in the form of closure or forgiveness for the survivors (Umbreit et al. 2003), because in very serious cases (murder, rape, and serious assault) restorative justice is ancillary or supplemental, not substitutionary, to formal adjudication. In its most spiritual forms, restorative justice is experienced as a cathartic event, both for victims and offenders. As one participant described it, "Today I have observed and taken part in justice administered with love" (Braithwaite 2002, p. 53). 
Indeed, some have asked whether an apology from a murderer might provide greater psychological closure (at least for some) than the death penalty (Hirsch 2006).

Perhaps the greatest empirical effort has been expended on examining what concrete and measurable effects restorative justice has had on recidivism rates. In a meta-analysis of 19 studies with 9307 offenders (juveniles), Nugent et al. (2003) found that VOM participants were $33 \%$ less likely to reoffend within six months than those who had not participated in VOM. This rigorous metaanalysis recognizes important categorical and coding issues-different studies define reoffense differently (arrest, conviction, any new contact with the criminal justice system), and the time period in which an offender is followed can have important effects on the findings. Generally speaking, over longer periods of time (as the offender moves further and further away from the VOM event), recidivism rates move closer together for restorative and conventional criminal justice participants (Nugent et al. 2003). These data must be compared with the general rates of decline in juvenile delinquency with the ordinary life course (which some estimate at as much as $50 \%$ who no longer offend when they grow older; see McCord 2000). Victimless crimes (like some forms of drunk-driving and some drug offenses) may be less subject to restorative justice-court differences as the encounter with a victim is minimal (with a state official standing in for the harm the crime caused) (Strang 2001). And comparisons of recidivism rates are subject to great selection biases, with the more minor crimes or those committed by juveniles more likely to be assigned to restorative, not conventional adjudicative, treatment conditions (Braithwaite 2002, Bazemore \& Walgrave 1999, Bradshaw et al. 2006, Pfeiffer 1998). Finally, empirical studies, with rare exception, tend to homogenize offenders and do not capture the offender who commits crime "for the thrill of it" and may not be deterred by either restorative justice or conventional criminal processes (Katz 1990).
John Braithwaite and other researchers studying regulatory enforcement have documented that compliance with regulations is often higher (and rates of repeated noncompliance lower) when regulated industries and corporate actors are actively engaged in discussions of compliance and allowed to talk with their regulators (Braithwaite 2002, Hawkins 1984). Inspections of mine safety (in the United States and the United Kingdom) that involved exit conferences with dialogues and plans for reparation were much more likely to lead to compliance with rules and increased safety standards. Braithwaite found that persuasion worked much more effectively in the corporate compliance context than did punitive measures. Similar results have been noted in nursing home regulation, special education (Handler 1986), and nuclear power regulation in a field now internationally called "communitarian regulation" (Rees 1988, 1994) [not unlike American reg-neg (negotiated rulemaking); see Harter 1982].

Uses of restorative justice in controversial arenas such as domestic abuse have met with criticism by feminists and some child advocates, but in fact many studies do report some success with nonrecidivism in some forms of family conferencing and other forms of restorative justice (Burford \& Pennell 1998). There has been less rigorous demonstration of successful uses of school peer mediation or antibullying to reduce school violence (Braithwaite 2002, pp. 59-61), although such efforts continue, especially in the wake of recent violent school shootings. Most of the United States was treated to its first public display of restorative justice when the Amish families who lost children in a school shooting in Pennsylvania forgave the wrongdoer, prayed with his widow, and created an image of freedom as "the freedom from vengeance, which is forgiveness" (Fleming 2006, Arendt 1998). Although not a restorative justice process with the actual offender (those who prayed together were all families of either the murderer or his victims and were, thus, all survivors), this demonstration of 
religious forgiveness was quite contrary to the images presented of more vengeful parents in other school shootings (such as Columbine, Colorado).

With the expansion of restorative justice to specialized reparative courts, like drug courts, vice courts, and unified family courts, researchers have just begun to explore rigorously whether new treatment models with less punishment reduce recidivism, increase employment, or have other ameliorative effects for both individuals and the larger community. Dorf \& Sabel (2000), for example, have studied drug courts' effectiveness and have argued that these experiments in local social control should be allowed to flourish and vary as evaluators seek to discover what works (such as ongoing relations with social workers and accountability to judges and other court personnel) in which contexts [big cities with larger budgets and more resources or smaller communities with more gemeinshaft or surveillance (depending on whether one has a Weberian or Foucaldian perspective)]. Courts that treat defendants as members of a community have been documented as being perceived to be more fair than conventional courts (Frazer 2006), and perceptions of fairness are linked to increased compliance (Tyler \& Huo 2002). These efforts to evaluate problem-solving courts are controversial, especially among those who see restorative justice institutions as formally abrogating legal rights in the name of remedial creativity (Thompson 2002). With restorative justice's analogue in the debate about use of bargaining processes for negotiated rulemaking in administrative regulation and civil law (Harter 1982, Coglianese 1997, Freeman 1997), critics fear that softer processes will undermine legal formality, separation of powers, formal legal accountability, and enforcement, as well as ordered norm and rule creation.

Evaluation of restorative justice's rehabilitative potential recapitulates the historical dialectic of all judicial reform. Nineteenthcentury reformers created juvenile courts to be a more responsive, less punitive, pater- nalistic institution for wayward youths. Civil libertarian litigation in the 1960s produced, among other cases, In re Gault (1967), which infused juvenile criminal proceedings with legal rights, such as the right to legal counsel and, some would argue, more punitive outcomes. Restorative justice, like its analogues in civil justice, is a reaction to an overrigidified, bureaucratized, punitive, and ineffective (at crime reduction) criminal law system, which now has its own critics for drawing different lines around individual and collective, formal and informal, material and spiritual, rights-based and interest-based values. Where restorative processes are supplemental, not substitutional, of the conventional legal process, they are more likely to be accepted. Yet some would prefer other reforms of the criminal justice system to remedy its problems. Some argue for less plea bargaining and faster, more responsive trials to allow defendants and victims to come to formal justice faster. Others argue for less draconian sentencing, both in length of time and severity, to return to earlier reform efforts at more rehabilitative notions of criminal remediation. Still others argue for decriminalization of certain offenses (minor property crimes, drug offenses) or more localization of criminal law enforcement, whereas more conservative forces argue for harsher sentences and criminalization of more offenses. In the political standoffs surrounding criminal justice policy, restorative justice appears to be one reform that appeals to both sides of the political spectrum, if for different reasons.

Beyond the conventional criminal justice system, efforts to expand restorative and reparative processes to larger acts of wrongdoing (Elster 2006) [state violence, genocide, civil wars, ethnic conflicts, international human rights violations, and past wrongs such as slavery and internment (Brophy 2006)] have also pitted restorative reformers against more formal rights-based reformers. The activity of nongovernmental organizations, the United Nations, and other organizations in enunciating and enforcing human rights 
standards has created whole new institutions of formal prosecution at the international level [the International Criminal Tribunal for the Former Yugoslavia (Hagan 2003) and for Rwanda and the International Criminal Court, among others]. Proponents of enforcement of international human rights argue for strict criminal prosecution, whereas others argue that some forms of reparative justice [whether individualized (Godobo-Madikizela 2003) or more collective (Keller 2007)] are more likely to lead to healed and functioning postconflict societies, replicating timeless philosophical debates about the relative efficacy of principle, adjudication, and rights versus interest- or needs-based bargaining (Elster 1995; Menkel-Meadow 1984, 2003). The rapid execution of Saddam Hussein after prosecution in a state (not international) tribunal, cutting off further testimony, information, and maybe public remorse, has reignited debates about how justice is delivered in such contexts. Whereas some tribunals have been international and other TRCs are nation-state based, other efforts have experimented with more mixed combinations of international and state-based institutions (Sierra Leone, East Timor). Meanwhile, complex legal issues of whether international bodies, such as the International Criminal Court, should bend to national policies of amnesty or forgiveness remain unresolved (Blumenson 2006).

Attempts to study the aftereffects of TRCs and more local, indigenous restorative processes, such as gacaca in Rwanda, now abound, with heated debate and controversy (Borer 2006, Henkin 2002, Rotberg \& Thompson 2000, Kritz 1995, Avruch \& Vejarano 2001, Hayner 2001) as many nations have filed formal truth reports with a variety of reparative conditions (Guatemala, Argentina, Chile, El Salvador, South Africa, Sierra Leone, East Timor). Questions of whether international or local principles of justice should govern are now being raised as well (for their effects on postconflict legitimacy of the legal processes used and the creation of new postconflict national identities, see Ivković \& Hagan 2006).
International tribunals are often viewed as aligned with one side in ethnic conflict, as some have argued has occurred in the International Criminal Tribunal for the former Yugoslavia, thus prolonging hostility and promoting continuing desires for vengeance.

Some decry the lack of participation by important perpetrators, such as Dyzanhaus's (2003) exposure of the absence in the South African TRC of apartheid-era judges, who failed even to narrate and acknowledge their crimes against humanity in upholding the legality of the apartheid regime. Others more forcefully critique the absence of any real punishment, accountability, or reparative compensation (Andrews \& Ellmann 2002, Abel 1995) for horrific wrongs, not to mention the failure to confront more long-lasting harmsnot only discrimination, wrongful murders and incarceration, and removal of civil liberties, but also continuing gross economic injustice, with little effort to ameliorate, even with well-written and democratically approved constitutions, the continuing conditions of inequality, poverty, and increasing crime among the have-nots. Some fear that having written a report and formally repented as a government, instead of "nunca mas!" (never again), Argentina and Chile, among others, could just as easily fall again into the clutches of brutal dictators (especially as Pinochet successfully avoided full accountability for his crimes). Whether postconflict or postdictatorship societies can put aside their past hostilities and sharp divisions and seek more moderate third ways or alternative strategies without fully coming to terms with the past remains to be seen. Democratically elected regimes are certainly fragile in the former Soviet Union and parts of Eastern Europe, whereas Latin America appears, as of this writing, to have turned a democratic corner, even while left and right cleavages remain strong in many countries. Optimistic citizens hope that past atrocities of military dictatorships have inoculated civil societies against ever again permitting them to exist, but history cautions against definitive conclusions, 
especially when economies are so volatile and inequality remains so pervasive, if not worse than in earlier decades. In the United States, arguments are made for truly restorative justice, not only in the nonmaterial form of apologies for slavery, Japanese American internment, and Native American genocide and property expropriation (Bradford 2005), but for material reparations to be paid to descendants of the victims of these social and political crimes (Brophy 2006, Ogletree 2002). Indigenous groups throughout the world have begun to make similar claims and to file national civil and international claims and lawsuits, seeking a variety of forms of justice, including land claims, monetary compensation, and self-determination and self-governance.

Nevertheless, as the debate between the past and future continues in the practices of truth and reconciliation panels or other forms of transitional justice and in the pages of scholarly reports, some rigorous empirical analysis has suggested that, as with the law of unintended consequences, other effects may be generated by such alternative justice systems. Gibson's (2004a,b) recent study of post-TRC South Africa demonstrates powerfully that those who viewed at least some of the televised Truth and Reconciliation proceedings were much more likely to adopt a human rights consciousness than were those who did not view any of the proceedings. Even in a setting with racially differentiated beliefs in the efficacy of the rule of law, exposure to the wrongful acts of apartheid and their public condemnation increased some perceptions of the need for political and racial tolerance and respect for minorities within a majoritarian rule of law conception. Thus, the transformative, educational effects of such processes may have benefits for those outside of the victim-offender dyad (and are why so many restorative justice projects seek to include community representation and some form of publicity or transparency). These processes are not only for the active participants or victims of the specific act of wrongdoing or harm. To the extent that formal justice systems are about providing public norms and accountability and remedying harm to the larger community, public restorative justice processes have been empirically demonstrated to provide educative, participatory, democracy-enhancing potential, through radically different formats and with potentially wider reaching effects.

\section{THE FUTURE OF RESTORATIVE JUSTICE: CHALLENGES AND OPPORTUNITIES}

Restorative justice is more of an idea, philosophy, set of values, or sensibility than a single concrete and uniform set of practices or processes. In some settings, there is direct communication, confrontation, and reconciliation of victims and offenders; in others, there is more indirect restorative justice (Tickell \& Akester 2004, Utab Law Review 2003, Marquette Law Review 2005), using procedures similar to caucusing or separate meetings, as in civil mediation, especially when direct communication between offenders and victims might make things worse or too painful (as in some murder, rape, and other serious crimes). In some settings, restorative justice is only for the victim and offender, promising safety, confidentiality, and tailored, individualized, reparative, and conciliatory outcomes. In other settings, more public participation is crucial [by those affected by the wrongful conduct, family members, supporters, treating or representative professionals, the larger community, and, in its most public forms such as TRCs, the larger society (O'Hear 2004, 2006)]. ${ }^{2}$ What began as an idea to reduce the punitive nature of conventional criminal punishment (especially for juvenile offenders and victimless crimes) and to improve the outcomes of criminal justice has developed into

\footnotetext{
${ }^{2}$ Restorative justice processes have been demonstrated in documentary films, focused on the actual operation of a variety of processes, or actually televised for an entire society, as with the South African TRC. More recently, restorative justice was depicted in a 2006 British film, Breaking and Entering by Anthony Minghella, which concludes with a juvenile criminal family conference in London.
} 
a social and political movement seeking to use restorative or reparative sensibilities to heal not only single acts of misconduct, but civil wars, genocides, and international, multiethnic, political, and religious conflict.

Restorative justice as a social movement has been both constituted by and works in collaboration with other political movements-peace studies, nonviolence advocates and practitioners, civil ADR and conflict resolution process proponents, international human rights activists, participatory and deliberative democracy theorists and practitioners (Menkel-Meadow 2005), and those who believe in responsive or dialogic regulation and justice (Pavlich 1996, 2005). What these movements have in common is a belief that more flexible, humane, dialogic, conversational, and authentic human engagement can end a cycle of misconduct, punishment, retribution, vengeance, and more bad acts and violence by both individualized and systematized processes of turning the other cheek, including authentic responsibility taking, accountability, and restitutionary outcomes leading to forgiveness, reconciliation, and reintegration. These are large, aspirational, almost utopian ideas and goals, informed by a basic optimism about humans' ability to engage in social learning and behavior modification at both individual and large group levels. Efforts to operationalize such grand notions at so many different levels are still experimental, evolving, and fragile. As social scientists and political leaders try to assess whether notions of reconciliation and reintegration can substitute for more punitive and retributivist institutions, they will have to confront a variety of challenges to these processes, including:

- Whether processes that may work on smaller scales (juvenile criminal offenders, community sentencing circles) can be scaled up to national and international conflict settings without compromising the basic ideas of restorative justice;
- Whether restorative justice requires shared values at the community, nationstate, or international level to be effective, or whether something less than unanimity or consensus can be appealed to in seeking human reconciliation after acts of wrongdoing;

- Whether the informality, confidentiality, and flexibility of restorative justice threatens important human and legal rights (publicity, representation, due process, anticonfessional rules, equity and proportionality in punishment) or whether human rights and human problem-solving processes can be reconciled;

- Whether informality, confidentiality, and flexibility in the sanctioning of wrongdoing compromises needs for public processes, public norm generation and enforcement, and transparency and equity;

- Whether restorative justice processes should be supplemental or substitutionary to more conventional processes of punishment and prosecution;

- Whether restorative justice processes themselves privilege some over others (the verbal, well resourced, represented, willing, clever, or manipulative);

- Whether authentic participation in restorative processes and rituals is possible in any mass, multi-valued, and diversely constituted community or society and whether participation in more micro, specific case situations can transform individuals and societies on a macro level to engage in more deliberative and responsive solutions to bad situations;

- Whether the basic philosophy of separating bad acts from bad people can be an effective notion for dealing with modern, group, and mass-level harmful acts.

These challenges are many and profound. Not listed above are the more practical challenges of structuring, supervising, and 
monitoring the operation and effectiveness of restorative justice programs. As restorative justice ideas are propelled from one domain to another, both ideas and institutionalized practices are themselves transformed to meet the needs of particular communities. There is always the danger of co-optation, both by the larger system and by individuals who learn to work the system with insincere apologies, offers of restitution or reparation, or other inauthentic performances. How insincere participation can and should be discovered and disciplined (in a nonfact-finding environment) remains a serious conundrum for restorative justice advocates. Whether rules, standards, and best practices can or should be generated to assure quality of process or some uniformity across or within domains remains an important policy issue in this field.

Yet, with all these challenges, we know that restorative justice has reduced recidivism and reoffense rates in many programs (with both juveniles and adults); that restorative justice processes, with more direct and responsive communication and negotiation, can generate new norms that are more reflective of changed circumstances or enhanced human understanding; and that even merely observing a restorative justice process or ritual can have social learning and transformative effects on how human beings conceive of their rights and responsibilities in a modern and diverse world. As social scientists develop rigorous evaluations of how these programs work in different settings, at different levels, with different purposes and structures, and with comparisons to relevant conventional processes, we will learn more about how restorative and reparative philosophies and practices may transform punitive forms of social control with more optimistic ideas about human empowerment, understanding, problem solving, and reconciliation after events of individual and group fissures. If, as the saying goes, you can get more bees with honey than with vinegar, perhaps we can get more social progress, peace, and justice with healing than with punishment.

\section{DISCLOSURE STATEMENT}

The author is not aware of any biases that might be perceived as affecting the objectivity of this review.

\section{LITERATURE CITED}

Abel R. 1982. The contradictions of informal justice. In The Politics of Informal fustice: Vol. 1. The American Experience, ed. RL Abel, pp. 267-320. New York: Academic

Abel R. 1995. Politics by Other Means (After the Law). London/New York: Routledge

Acorn A. 2004. Compulsory Compassion: A Critique of Restorative Fustice. Vancouver: Univ. B.C. Press

Andrews P, Ellmann S. 2002. The Post-Apartheid Constitutions: Perspectives on South Africa's Basic Law. Johannesburg, So. Afr: Witwatersrand Univ. Press

Arendt H. 1998. The Human Condition. Chicago: Univ. Chicago Press. 2nd ed.

Avruch K, Vejarano B. 2001. Truth and reconciliation commissions: a review essay and annotated bibliography. Soc. Fustice: Anthropol. Peace Hum. Rights 2(1-2):47-108

Barnett R. 1977. Restitution: a new paradigm of criminal justice? Ethics 87:279-301

Bazemore G, Walgrave L, eds. 1999. Restorative fuvenile fustice: Repairing the Harm of Youth Crime. Monsey, NY: Crim. Justice Press

Beale SS. 2003. Still tough on crime? Prospects for restorative justice in the United States. Utab Law Rev. 2003:413-37 
Berman G, Feinblatt J, Glazer S. 2005. Good Courts: The Case for Problem Solving Fustice. New York: New Press

Blumenson E. 2006. The challenge of global standard of justice: peace, pluralism and punishment at the International Criminal Court. Columbia 7. Transnatl. Law 44:801-74

Bohman J. 1996. Public Deliberation: Pluralism, Complexity and Democracy. Cambridge, MA: MIT Press

Bolocan MG. 2004. Rwandan gacaca: an experiment in transitional justice. F. Disput. Resolut. 2004(2):355-400

Borer TA, ed. 2006. Telling the Truths: Truth Telling and Peace Building in Post-Conflict Societies. Notre Dame, IN: Notre Dame Press

Bradford W. 2005. Beyond reparations: an American Indian theory of justice. Obio St. Law 7. 66:3-104

Bradshaw W, Roseborough D, Umbreit MS. 2006. The effect of victim offender mediation on juvenile offender recidivism: a meta-analysis. Confl. Resolut. Q. 24(1):87-98

Braithwaite J. 1989. Crime, Shame and Reintegration. Cambridge, UK: Cambridge Univ. Press

Braithwaite J. 1995. Reintegrative shaming, republicanism and policy. In Criminology and Public Policy: Putting Theory to Work, ed. H Barlow, pp. 191-205. Boulder, CO: Westview

Braithwaite J. 1999. Restorative justice: assessing optimistic and pessimistic accounts. Crime Fustice 25:1-127

Braithwaite J. 2002. Restorative Fustice and Responsive Regulation. Oxford: Oxford Univ. Press

Braithwaite J. 2003. Holism, justice and atonement. Utab Law Rev. 2003:389-412

Braithwaite J. 2006. Narrative and “compulsory compassion.” Law Soc. Inq. 31(2):425-46

Brooks RL, ed. 1999. When Sorry Is Not Enough: The Controversy Over Apologies and Reparations for Human Injustice. New York: NY Univ. Press

Brophy AL. 2006. Reparations: Pro and Con. London/New York: Oxford Univ. Press

Brown JG. 1994. The use of mediation to resolve criminal cases: a procedural critique. Emory Law Rev. 43:1247-309

Burford G, Pennell J. 1998. Family Group Decision Making Project: Vol. 1. Outcome Report. St. John's: Memorial Univ. Newfoundland, Sch. Soc. Work

Cahn N. 2006. Women in post-conflict reconstruction: dilemmas and directions. William Mary 7. Women's Law 12:335

Christie N. 1977. Conflicts as property. Br. F. Criminol. 17:1-5

Coates RB, Gehm J. 1985. Victim Meets Offender: An Evaluation of Victim-Offender Reconciliation Programs. Valparaiso, IN: PACT Inst. Justice

Coglianese C. 1997. Assessing consensus: the promise and performance of negotiated rulemaking. Duke Law Rev. 46:1255-349

Daly K. 2002. Restorative justice: the real story. Punishm. Soc. 4(1):55-79

Daly K. 2005. Feminist engagement with restorative justice. Theor. Criminol. 9(4):9-28

Davis RC, Tichane M, Grayson D. 1980. Mediation and Arbitration as Alternatives to Prosecution in Felony Arrest Cases: An Evaluation of the Brooklyn Dispute Resolution Center. New York: VERA Inst. Justice

Delgado R. 2000. Goodbye to Hammarabi: analyzing the atavistic appeal of restorative justice. Stanford Law Rev. 52:751-75

Dolinko D. 2003. Restorative justice and the justification of punishment. Utab Law Rev. 2003:319-42

Dorf MC, Sabel CF. 2000. Drug treatment courts and emergent experimentalist government. Vanderbilt Law Rev. 53:831-83

Dyzenhaus D. 2003. Fudging the fudges: Fudging Ourselves: Truth, Reconciliation and the Apartheid Legal Orders. Oxford: Hart 
Elster J. 1995. Strategic uses of argument. In Barriers to Conflict Resolution, ed. K Arrow, RH Mnookin, L Ross, A Tversky, R Wilson, pp. 236-57. New York: Norton

Elster J, ed. 2006. Retribution and Reparation in the Transition to Democracy. Cambridge, UK: Cambridge Univ. Press

Ervin L, Schneider AL. 1990. Explaining the effects of restitution on offenders: results from a national experiment in juvenile courts. In Criminal fustice: Restitution and Reconciliation, ed. B Galaway, J Hudson, pp. 183-206. Monsey, NY: Crim. Justice Press

Fleming AT. 2006. The tender face of religion. National Public Radio, Oct. 6

Foucault M. 1979. Discipline and Punish: The Birth of the Prison. New York: Vintage Books

Frazer MS. 2006. The Impact of the Community Court Model on Defendant Perceptions of Fairness: A Case Study at the Red Hook Community fustice Center. New York: Cent. Court Innov.

Freeman J. 1997. Collaborative governance and the administrative state. UCLA Law Rev. 45:198

Gabbay Z. 2005. Justifying restorative justice: a theoretical justification for the use of restorative justice practices. 7. Disput. Resolut. 2005(2):349-97

Gibson JL. 2004a. Overcoming Apartheid: Can Truth Reconcile a Divided Nation? New York: Russell Sage Found.

Gibson JL. 2004b. Truth, reconciliation and the creation of a human rights culture in South Africa. Law Soc. Rev. 38(2):5-40

Godobo-Madikizela P. 2003. A Human Being Died That Night: A South African Story of Forgiveness. Boston: Houghton Mifflin

Grillo T. 1991. The mediation alternative: process dangers for women. Yale Law 7 . 100:1545-81

Hagan J. 2003. Fustice in the Balkans: Prosecuting War Crimes in the Hague Tribunal. Chicago: Univ. Chicago Press

Haley J, Neugebauer AM. 1992. Victim-offender mediation: Japanese and American comparisons. In Restorative Fustice on Trial: Pitfalls and Potentials of Victim-Offender Mediation-International Research Perspectives, ed. H Messner, HU Otto, pp. 105-30. Dordrecht/Boston: Kluwer Acad.

Handler J. 1986. The Conditions of Discretion: Autonomy, Community, Bureaucracy. New York: Russell Sage Found.

Harter P. 1982. Negotiating regulations: a cure for the malaise. Georgetown Law 7. 71:1-113

Hawkins K. 1984. Environment and Enforcement: Regulation and Social Definition of Pollution. Oxford: Clarendon

Hayner PB. 2001. Unspeakable Trutbs: Confronting State Terror and Atrocities. New York: Routledge

Henkin A, ed. 2002. The Legacy of Abuse: Confronting the Past, Facing the Future. New York: Aspen Inst. Justice Soc. Program

Hirsch SF. 2006. In the Moment of Greatest Calamity: Terrorism, Grief and a Victim's Quest for Fustice. Princeton, NJ: Princeton Univ. Press

Honeyman C. 2004. Potentials for participatory justice in Rwanda: the gacaca jurisdictions. Peace Confl.: F. Peace Psychol. 10:1-24

In Re Gault, 387 U.S. 1 (1967)

Ivković SK, Hagan J. 2006. The politics of punishment and the siege of Sarajevo: toward a conflict theory of perceived international (in)justice. Law Soc. Rev. 40:369-410

Johnstone G. 2003. A Restorative fustice Reader: Text, Sources, Context. Cullompton, Devon, UK/Portland, OR: Willan

Kahan DM. 1996. What do alternative sanctions mean? Univ. Chicago Law Rev. 63:591-653

Kahan DM. 2006. What's really wrong with shaming sanctions. Texas Law Rev. 84:2075 
Kakalik JS, Dunworth T, Hill LA, McCaffrey D, Oshiro M, et al. 1996. An Evaluation of Mediation and Early Neutral Evaluation Under the Civil fustice Reform Act. Santa Monica, CA: RAND Corp.

Katz J. 1990. Seductions of Crime. New York: Basic Books

Kaye J. 1997. Changing courts in changing times: the need for a fresh look at how courts are run. Hastings Law 7. 48:851-66

Keller LM. 2007. Seeking justice at the international criminal court: victim's reparations. Thomas fefferson Law Rev. In press

Kritz N, ed. 1995. Transitional fustice: How Emerging Democracies Reckon with Former Regimes. Washington, DC: US Inst. Peace Press

Kuhn A. 1987. A review and assessment of victim-offender reconciliation programming in West Germany. In Criminal fustice, Restitution and Reconciliation, ed. B Galaway, J Hudson, pp. 109-24. Monsey, NY: Crim. Justice Press

LaFree G, Rack C. 1996. The effects of participants' ethnicity and gender on monetary outcomes in mediated and adjudicated civil cases. Law Soc. Rev. 30:767-97

Langbein JH. 2003. The Origins of Adversary Criminal Trial. Oxford: Oxford Univ. Press

Latimer J, Dowden C, Musie D. 2001. The Effectiveness of Restorative fustice Practices: A MetaAnalysis. Ottawa: Res. Stat. Div., Dep. Justice

Lederach JP. 1997. Building Peace: Sustainable Reconciliation in Divided Societies. Washington, DC: US Inst. Peace Press

Lerman D. 1999. Restoring justice. Tikkun 14:13-15

Levrant S, Cullen FT, Fulton B, Wozniak JF. 1999. Reconsidering restorative justice: the corruption of benevolence revisited. Crime Delinq. 45:3-27

Lind EA, MacCoun RJ, Ebener PA, Felstiner WLF, Hensler DR, et al. 1989. The Perception of Justice: Tort Litigants' Views of Trial, Court-Annexed Arbitration and Fudicial Settlement Conferences. Santa Monica, CA: RAND Corp.

Llewellyn J, Howse R. 1998. Restorative Justice: A Conceptual Framework. Ottawa, ON: Law Comm. Can.

Luban D. 1995. Settlements and the erosion of the public realm. Georgetown Law 7. 83:2619

MacCoun RJ. 2005. Voice, control and belonging: the double-edge sword of procedural fairness. Annu. Rev. Law Soc. Sci. 1:171-201

Markel D. 2007. Still wrong? Professor Kahan on the fall of shaming and the rise of restorative justice. Texas Law Rev. In press

Marquette Law Rev. 2005. Symposium: restorative justice in action. Marquette Law Rev. 89:247358

Marshall TF. 1998. Restorative fustice: An Overview. Minneapolis, MN: Cent. Restorat. Justice Peacemak.

Marshall TF, Merry S. 1990. Crime and Accountability: Victim Offender Mediation in Practice. London: Home Office

Matoesian GM. 1993. Reproducing Rape: Domination Through Talk in the Courtroom. Chicago: Univ. Chicago Press

Maxwell GM, Morris A. 1993. Families, Victims and Culture: Youth Justice in New Zealand. Wellington: Victoria Univ. Wellington, Inst. Criminol.

McCold P, Wachtel B. 1998. Restorative Policing Experiment: The Bethlehem Pennsylvania Police Family Group Conferencing Project. Pipesville, PA: Community Serv. Found.

McCord J. 2000. A theory of motivation and the life course. In Social Dynamics of Crime and Control: New Theories for a World in Transition, ed. S Karstedt, K Bussman, pp. 229-42. Oxford: Hart 
Menkel-Meadow C. 1984. Toward another view of legal negotiation: the structure of problem solving. UCLA Law Rev. 31:754-849

Menkel-Meadow C. 1995. Whose dispute is it anyway? A philosophical and democratic defense of settlement (in some cases). Georgetown Law 7. 83:2663-91

Menkel-Meadow C. 2003. Introduction: from legal disputes to conflict resolution and legal problem solving. In Dispute Processing and Conflict Resolution: Theory, Practice and Policy, ed. C Menkel-Meadow, pp. xi-xlii. Aldershot, UK: Ashgate-Dartmouth

Menkel-Meadow C. 2004. Remembrance of things past? The relationship of past to future in pursuing justice in mediation. Cardozo 7. Confl. Resolut. 5:97-115

Menkel-Meadow C. 2005. The lawyers' role in deliberative democracy. Nev. Law Rev. 5:347-69

Menkel-Meadow C. 2006. Peace and justice: notes on the evolution and purposes of legal processes. Georgetown Law 7. 94(2):553-80

Menkel-Meadow C, Love LP, Schneider AK, Sternlight J. 2005. Dispute Resolution: Beyond the Adversarial Model. New York: Aspen

Minow M. 1998. Between Vengeance and Forgiveness: Facing History After Genocide and Mass Violence. Boston: Beacon

Nonet P, Selznick P. 1978. Law and Society in Transition: Toward Responsive Law. Berkeley: Univ. Calif. Press

Nugent W, Williams M, Umbreit MS. 2003. Participation in victim-offender mediation and the prevalence and severity of subsequent delinquent behavior: a meta-analysis. Utah Law Rev. 2003:137-66

Nussbaum M. 2004. Hiding from Humanity: Disgust Shame and the Law. Princeton, NJ: Princeton Univ. Press

Ogletree CJJ. 2002. Reparations: a fundamental issue of social justice. Black Coll. 33:118-22

O’Hear MM. 2004. Revisiting informal justice: restorative justice and democratic professionalism. Law Soc. Rev. 38:139

O'Hear MM. 2006. Victims and criminal justice: What's next? Fed. Sentencing Report. 19(2):8390

Pavlich G. 1996. The power of community mediation: government and formation of identity. Law Soc. Rev. 30:707-33

Pavlich G. 2005. Governing Paradoxes of Restorative fustice. London: Glasshouse

Pfeiffer C. 1998. Juvenile crime and violence in Europe. Crime Fustice 23:255-328

Poulson B. 2003. A third voice: a review of empirical research on the psychological outcomes of restorative justice. Utab Law Rev. 2003:167-203

Raper J. 2005. The gacaca experiment: Rwanda's restorative dispute resolution response to the 1994 genocide. Pepperdine Dispute Resolut. Law 7. 5:1-56

Rees JV. 1988. Reforming the Workplace. Philadelphia: Univ. Penn. Press

Rees JV. 1994. Hostages of Each Other: The Transformation of Nuclear Safety Since Three Mile Island. Chicago: Univ. Chicago Press

Robinson PH. 2003. The virtues of restorative processes, the vices of "restorative justice." Utah Law Rev. 2003:375-88

Robinson PH. 2006. Restorative processes \& doing justice. Univ. St. Thomas Law 7. 3:421-29

Roche D, ed. 2004. Restorative fustice. Aldershot, UK/Burlington, VT: Ashgate-Dartmouth

Rotberg RI, Thompson D, eds. 2000. Truth v. Justice: The Morality of Truth Commissions. Princeton, NJ: Princeton Univ. Press

Rugge T, Cormier R. 2005. Restorative justice in cases of serious crimes: an evaluation. In New Directions in Restorative fustice: Issues, Practice and Evaluation, ed. E Elliott, RM Gordon, pp. 266-77. Cullompton, Devon, UK: Willan 
Stein AA. 1993. Why Nations Cooperate: Circumstances and Choice in International Relations. Ithaca, NY: Cornell Univ. Press

Strang H. 2001. Victim Participation in a Restorative fustice Process. Oxford: Oxford Univ. Press

Strang H. 2004. Repair or Revenge: Victims and Restorative Fustice. Oxford: Clarendon

Strang H, Barnes GC, Braithwaite J, Sherman LW. 1999. Experiments in Restorative Policing: A Progress Report on the Canberra Reintegrative Shaming Experiments (RISE). Canberra: Aust. Natl. Univ. http://www.aic.gov.au/rjustice/rise/progress/1999.html

Strang H, Braithwaite J. 2000. Restorative fustice: Philosophy to Practice. Aldershot, UK/Burlington, VT: Ashgate-Dartmouth

Stromseth J, Wippman D, Brooks R. 2006. Can Might Make Rights? Building the Rule of Law After Military Interventions. Cambridge, UK: Cambridge Univ. Press

Stuart B. 2001. Guiding principles for peacemaking circles. In Restorative Community Fustice: Repairing Harm and Transforming Communities, ed. G Bazemore, M Schiff, pp. 219-41. Cincinnati, $\mathrm{OH}$ : Anderson

Stubbs J. 1995. Communitarian conferencing and violence against women: a cautionary note. In Wife Assault and the Canadian Criminal fustice System, ed. M Valverde, L MacLeod, K Johnson, pp. 260-89. Toronto: Cent. Criminol., Univ. Toronto

Teitel RG. 2000. Transitional fustice. New York: Oxford Press

Thibault JW, Walker L. 1975. Procedural Fustice: A Psychological Perspective. Hillsdale, NJ: Erlbaum

Thompson AC. 2002. Courting disorder: some thoughts on community courts. Wash. Univ. $\mathcal{F}$. Law Policy 10:63-99

Thompson EP. 1976. Albion's Fatal Tree. New York: Pantheon

Tickell S, Akester K. 2004. Restorative Fustice: The Way Abead. London: Justice

Tutu D. 1999. No Future Without Forgiveness. New York: Doubleday

Tyler TR, Huo YJ. 2002. Trust in the Law. New York: Russell Sage Found.

Umbreit MS. 1994. Victim Meets Offender: The Impact of Restorative Fustice and Mediation. Monsey, NY: Crim. Justice Press

Umbreit MS. 1995. Mediation of Criminal Conflict: An Assessment of Programs in Four Canadian Provinces. St. Paul: Cent. Restor. Justice Mediat., Univ. Minn.

Umbreit MS. 2001. The Handbook of Victim Offender Mediation: An Essential Guide to Practice and Research. San Francisco: Jossey-Bass

Umbreit MS, Coates RB. 1992. Victim Offender Mediation: An Analysis of Programs in Four States of the US. Minneapolis: Citizen Counc. Mediat. Serv.

Umbreit MS, Coates RB, Vos B. 2001. The impact of victim offender mediation: two decades of research. Fed. Probat. 65:29-35

Umbreit MS, Coates RB, Vos B. 2005. Victim offender mediation: evidence-based practice over three decades. In The Handbook of Dispute Resolution, ed. ML Moffitt, RC Bordone, pp. 455-70. San Francisco: Jossey-Bass

Umbreit MS, Ritter R. 2006. Arab offenders meet Jewish victims: restorative family dialogue in Israel. Confl. Resolut. Q. 24(1):99-109

Umbreit MS, Roberts AW. 1996. Center for Restorative fustice \& Mediation, Mediation of Criminal Conflict in England: An Assessment of Services in Coventry and Leeds. St. Paul: Cent. Restor. Justice Mediat., Univ. Minn.

Umbreit MS, Vos B, Coates RB, Brown K. 2003. Facing Violence: The Path of Restorative fustice and Dialogue. Monsey, NY: Crim. Justice Press

Utah Law Rev. 2003. Symposium: the practice of restorative justice. Utab Law Rev. 2003:1-533

Utz PJ. 1978. Settling the Facts: Discretion and Negotiation in Criminal Court. Lexington, MA: Lexington Books 
Van Ness DW. 1993. New wine and old wineskins: four challenges of restorative justice. Crim. Law Forum 4:251-76

Von Hirsh A, ed. 2003. Restorative fustice and Criminal fustice: Competing or Reconcilable Paradigms? Portland, OR: Hart

Weisberg R. 2003. Restorative justice and the danger of "community." Utab Law Rev. 2003:34374

Wellikoff I. 2004. Victim offender mediation and violent crimes: on the way to justice. Cardozo Online 7. Confl. Resolut. 5:2

Wyrick P, Costanzo M. 1999. Predictors of client participation in victim-offender mediation. Mediat. Q. 16:253-57

Yazzie R, Zion JW. 1996. Navajo restorative justice: the law of equality and justice. In Restorative Fustice: International Perspectives, ed. B Galaway, J Hudson, pp. 144-51. Monsey, NY: Crim. Justice Press

Young IM. 1990. Fustice and the Politics of Difference. Princeton, NJ: Princeton Univ. Press

Young IM. 2000. Inclusion and Democracy. Oxford: Oxford Univ. Press

Zehr H. 1990. Changing Lenses: A New Focus for Crime and Justice. Scottdale, PA: Herald

Zehr H. 2002. The Little Book of Restorative fustice. Intercourse, PA: Good Books

Zehr H, Mika H. 1998. Fundamental concepts of restorative justice. Contemp. Fustice Rev. $1: 47-55$

Zimring FE. 2006. The Great American Crime Decline. New York: Oxford Univ. Press 